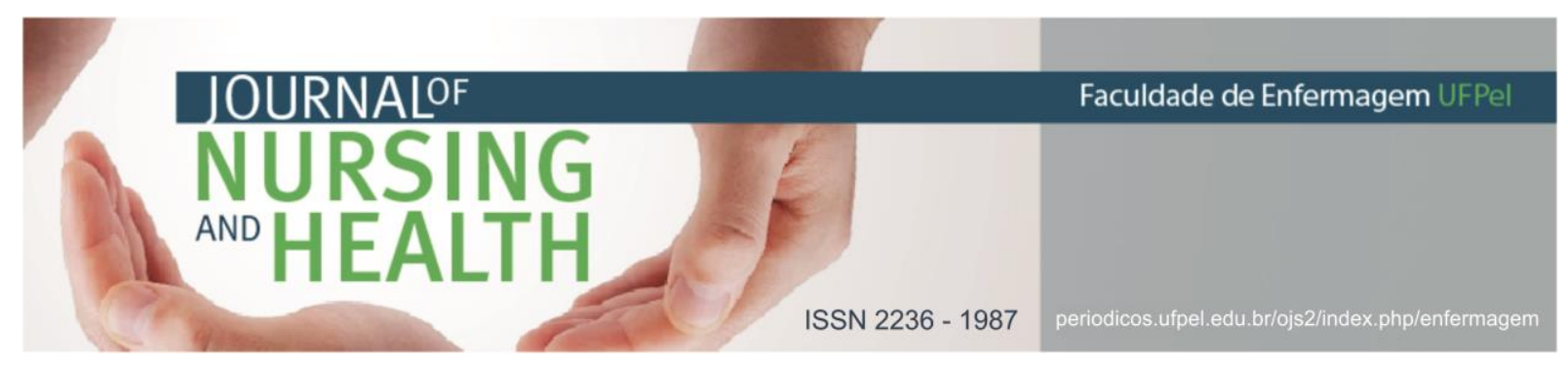

ENTREVISTA NARRATIVA

\title{
Um pouco da história da formação de um grupo de ouvidores de vozes: entrevista com Abmael de Sousa Alves
}

\section{A little bit of the history of the formation of a voice hearers group: interview with Abmael de Sousa Alves}

Un poco de la historia de la formación de un grupo de oyentes de voces: entrevista con Abmael de Sousa Alves

Sousa, Afra Suelene de ${ }^{1}$; Souza, Gabriela Lobato de ${ }^{2}$

Como citar este artigo: Sousa AS, Souza GL. Um pouco da história da formação de um grupo de ouvidores de vozes: entrevista com Abmael de Sousa Alves. J. nurs. health. 2018;8(n.esp.):e188426

Palavras-chaves: Saúde mental; Ouvir vozes; Luta antimanicomial.

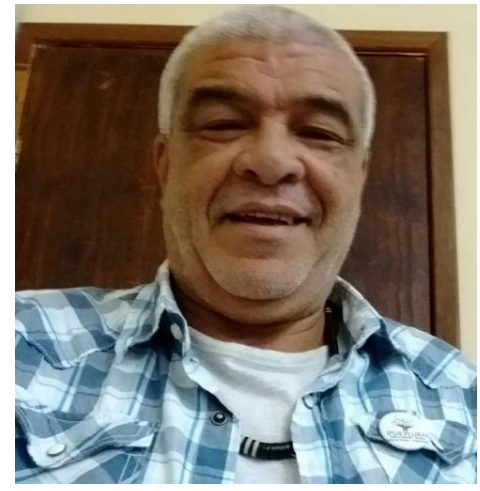

Com a palavra, o entrevistado

\section{APRESENTAÇÃO}

A presente narrativa foi produzida a partir de uma entrevista realizada com Abmael de Sousa Alves, participante da Comissão Organizadora do I Congresso Nacional de Ouvidores de Vozes, realizado pelo Instituto de Psiquiatria da Universidade Federal do Rio de Janeiro (IPUB/UFRJ) de 20 a 21 de outubro de 2017.

Sou Abmael de Sousa Alves, tenho 63 anos, minha formação é em terapia ocupacional e pedagogia, com habilitação em educação especial. Me graduei tardiamente por volta dos 30 ou 31 anos, e escolhi essa habilitação na pedagogia porque tinha afinidade com o que já trabalhava, saúde mental (acolhimento às pessoas com transtornos mentais). Também tenho pósgraduação em sexualidade humana e relacionamento amoroso. Pretendo fazer o mestrado profissional no IPUB/UFRJ, pois considero que esta formação tem mais proximidade com o meu perfil profissional, por ser mais prático, mais despojado como eu sou.

\footnotetext{
1 Enfermeira. Doutora em Educação. Universidade Federal de Pelotas (UFPEL). E-mail: afrasus@uol.com.br http://orcid.org/0000-0001-9636-4762

2 Enfermeira. Mestre em Política Social. Instituto Federal Sul Rio-Grandense (IFSUL). E-mail: gaby_lobato@yahoo.com.br http://orcid.org/0000-0003-3415-588X
} 


\section{NURSING \\ AND

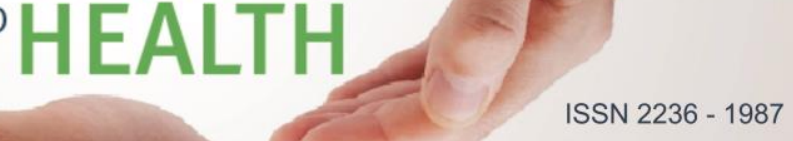

Estou em processo para aposentadoria, mas não o fiz pela paixão $e$ comprometimento com a saúde mental. Sou militante da reforma psiquiátrica e da luta antimanicomial há mais 30 anos. Atualmente trabalho como terapeuta ocupacional no IPUB/UFRJ. Por divergências com algumas pessoas do corpo diretivo deste instituto, estive afastado durante oito anos, retornei no ano de 2012. Nesse período trabalhei em um ambulatório e em dois Centro de Atenção Psicossocial (CAPS) do município do Rio, ocupei cargos de responsável técnico e diretor.

A militância na luta antimanicomial e aproximação com a questão dos ouvidores de vozes

Sou militante há mais 30 anos, participo da luta antimanicomial desde que me entendo por gente. A partir dos anos 80 é que se começa a formatar a minha luta de maneira mais ativa, junto com os usuários, familiares e profissionais, hasteando bandeiras, mesmo já tendo trabalhado em instituições totais, mas sabendo que naquele lugar eu tinha um objetivo que era melhorar e mudar as práticas de cuidado das pessoas com transtorno mental. Tenho também colegas de trabalho que considero como pessoas importantes na militância da reforma psiquiátrica que me estimularam a seguir a trajetória dos ouvidores de vozes. Eu sempre na minha prática profissional gostei dessa questão das narrativas dos pacientes, o que eles diziam, e explorar o máximo que puder para que eu possa dar um retorno daquilo, acolher, estar junto. E assim, nos anos 90 quando a Erotildes Maria Leal e Octavio Serpa começaram de forma tímida a fazer pesquisa sobre o ouvir vozes, fui achando interessante.

\section{A retomada do grupo de ouvidores de vozes a partir do treinamento de Paul Baker}

Quando retornei ao IPUB/UFRJ estava fazendo um curso de especialização em Gestão de CAPS e conhecia a Octávia Cristina Barros e muitos outros amigos que também faziam o mesmo curso. Logo após a Octávia entra no mestrado. Octavio Serpa me convidou para fazer parte de um grupo chamado "a voz dos usuários" que é um projeto com histórias de superação que a gente tem aqui no IPUB, cujo objetivo é o protagonismo do usuário. A partir daí, comecei a me interessar mais ainda pela temática sobre ouvidores de vozes, e aí apareceu a oportunidade para fazer um treinamento com Paul Baker que é um dos fundadores do movimento de ouvidores de vozes da Inglaterra. Ele veio aqui em 2015. Durante esse curso ocorreu uma dinâmica no auditório que estava cheio. Nela o Paul Baker instruía que se conversasse com a pessoa ao lado. Observei a Octávia conversando com um usuário e aquilo me despertou $e$ causou tanta coisa...

Nesta época a Octávia estava escrevendo sua dissertação sobre ouvidores, $e$ precisava de um espaço acolhedor para transcrever, então juntou a 'fome com a vontade de comer'. O grupo começou de uma forma assim, em que falávamos 
em uma assembleia para os pacientes, fundamentado em material que nós tínhamos do Paul Baker e baseado no treinamento que a gente fez com ele, em que quatro ou seis usuários também participaram, e assim posso dizer que facilitou, a gente construiu junto.

Já existia um grupo de ouvidores de vozes no hospital-dia em um formato que eu não tenho conhecimento e era feito por uma musicoterapeuta que se aposentou. Esse grupo ficou quatro ou cinco anos sem funcionar.

O grupo de ouvidores de vozes reúne-se semanalmente, desde junho de 2015, desde que o Paul Baker ministrou o treinamento. É importante salientar que é um grupo interinstitucional, ou seja, acolhe/recebe os usuários de todos os serviços da rede.

\section{REFERÊNCIAS}

1 Baker P. The voice inside: a practical guide to coping with hearing voices. Toronto: Canadian Mental Health Association; 2012.

2 Kantorski LP; Andrade APM de; Cardano M. Estratégias, expertise e experiências de ouvir vozes: entrevista com Cristina Contini. Interface comun saúde educ [Internet]. 2017 [acesso em 2018 set 10];21(63):1039-48. Disponível em: http://www.scielo.br/pdf/icse/v21n63/1807-5762-icse-21-63-1039.pdf 